SISTEMA
ELETRÔNICO
DE REVISTAS
SER I UfPR

\title{
Green cosmetics: perspectives and challenges in the context of green chemistry
}

\section{Cosméticos verdes: perspectivas e desafios no contexto da química verde}

\author{
Camilla Custoias Vila FRANCA ${ }^{1}$, Helene Mariko $\mathrm{UENO}^{1 *}$ \\ ${ }^{1}$ University of São Paulo (USP), São Paulo, São Paulo, Brazil. \\ *E-mail of contact: papoula@usp.br
}

Article received on October 15, 2018, final version accepted on February 21, 2020, published on April $27,2020$.

ABSTRACT: Green cosmetics present ecological appeals and claim to be developed according to the principles of Green Chemistry. Green Chemistry can be defined as the set of processes and products that reduces or eliminates the use or generation of hazardous substances. Despite the growing market, there are gaps related to the scope and regulation of these products. The article consists of a literature review on conceptual, regulatory and risk analysis limitations and perspectives of green cosmetics. We conducted searches in databases of scientific articles and analysis of publications by government agencies and organic/natural cosmetic certification systems. From the data collected, we found that there is a lack of government definitions and regulations for green cosmetics in the United States, the European Union and Brazil, and there are divergences between the guidelines adopted by green cosmetic certification systems, although we identified attempts to harmonize these guidelines. There was also a lack of approaches to the risk assessment of these products. The identification of limitations and perspectives on green cosmetics can be considered the first step to overcome these difficulties, promoting the dissemination of these products and maximizing their potential in reducing the risks to human and environmental health presented by cosmetics, following the principles of Green Chemistry.

Keywords: personal care products; organic; natural; certification systems; pollution prevention.

RESUMO: Os cosméticos verdes apresentam apelos ecológicos e afirmam ser desenvolvidos de acordo com os princípios da Química Verde. A Química Verde pode ser definida como o conjunto de processos e produtos que reduz ou elimina o uso ou a geração de substâncias perigosas. Embora haja um mercado crescente, existem lacunas relacionadas ao escopo e à regulamentação desses produtos. $\mathrm{O}$ artigo consiste em uma revisão bibliográfica sobre as perspectivas e limitações conceituais, regulatórias e relativas à análise de risco dos cosméticos verdes. Foram realizadas buscas em bases de dados de artigos científicos e análise de publicações de agências governamentais e de sistemas de certificação de cosméticos orgânicos/naturais. A partir dos dados coletados, 
verificou-se a falta de definições e regulamentações governamentais para cosméticos verdes nos Estados Unidos, na União Europeia e no Brasil e a existência de divergências entre as diretrizes adotadas pelos sistemas de certificação de cosméticos verdes, embora tenhamos identificado tentativas de harmonização dessas diretrizes. Verificamos também a falta de abordagens para a avaliação de risco desses produtos. A identificação das perspectivas e limitações dos cosméticos verdes pode ser considerada como o primeiro passo para transpor essas dificuldades, promovendo a disseminação desses produtos e maximizando seu potencial na redução dos riscos à saúde humana e ambiental apresentados pelos cosméticos, seguindo os princípios de Química Verde.

Palavras-chave: produto de cuidados pessoais; orgânico; natural; sistemas de certificação; prevenção da poluição.

\section{Introduction}

The Global Beauty Market refers to the production and marketing of cosmetics and personal care products. In the last 20 years, this market has grown $4.5 \%$ a year on average, showing a trend of increasing demand, especially in the emerging markets of Asia and Latin America (Łopaciuk \& Loboda, 2013). The scenario is also characterized by the emergence of new products, which is constantly driven by the spread of ever more demanding beauty standards.

However, the increase of the public concern about the use of hazardous chemicals in cosmetics and the emergence of ethical concerns related to the cosmetics industry boosted the organic cosmetics market. The global revenue of organic cosmetics in 2018 has been estimated at USD 13.33 billion (Grand View Research, 2019). According to consultancy company Kline, natural cosmetics and skincare were estimated to be worth $\$ 33$ billion in 2015 , accounting for $13 \%$ of the overall global beauty market, and is predicted to hit $\$ 50$ billion by 2019 (Pike, 2015).

Organic and natural cosmetics are generally associated with the "green" attribute (Leja \&
Ross-Fichter, 2014), which is used to designate products that have ecological appeals and follow specific production principles. In the case of green cosmetics, common claims are those that ensure that the products are developed in accordance with the principles of Green Chemistry. Green Chemistry can be defined as the use of a set of principles that reduces or eliminates the use or generation of hazardous substances in the design, manufacture and application of chemicals (Anastas \& Warner, 1998) so that they pose a lower risk to human health and the environment.

However, it is possible to highlight some questions about green cosmetics: How is it possible to ensure that certain products follow the principles of Green Chemistry? What characteristics are necessary for a cosmetic to be considered "green"? Are there standard guidelines to be followed by green cosmetics producers? How can the consumer be informed about the differential characteristics and benefits of these products?

This paper can be considered as the first step in addressing these issues. The aim of this study is to analyze the state of the art of green cosmetics, focusing on the conceptual, regulatory and risk assessment limitations and perspectives of these 
products in the context of Green Chemistry. It consists of exploratory documentary research in databases of scientific articles and the analysis of publications of governmental agencies and organic/ natural cosmetic certification systems on aspects su$\mathrm{ch}$ as the definition, regulation and risk assessment of these products.

The small number of scientific articles produced emphasizes the relevance of approaches focused on conceptual/theoretical aspects of the subject. By identifying the main obstacles and opportunities for the dissemination of green cosmetics based on theoretical analyses, we discuss key elements that contribute to overcome these obstacles, aiming to promote a better characterization of these products in the market and reduce the dissemination of misleading advertisements about green cosmetics, and, thus, to practical applications as well.

\section{Method}

The study comprises literature review, based on exploratory documentary research and the analysis and interpretation of publications in scientific journals, governmental agencies and organic/natural cosmetic certification systems. The research on publications of governmental agencies and certification systems involved searches on websites, technical guides, laws, regulations and decrees.

Surveys of scientific articles were carried out in the $\operatorname{Scopus}{ }^{\circledR}$ database. The searches were performed in advanced form. The fields "subject/ descriptor" (or equivalent) and "words of title" were used with the terms "green cosmetics", "organic cosmetics" and "natural cosmetics". The terms were related to each other through the Boolean operator
"OR" to identify papers that dealt with the topic. Subsequently, the operators "AND" was used to restrict the topic to the aspects to be discussed: definition, regulation and risk analysis or assessment. The criterion of inclusion of the articles refers to the language, since we selected only publications in English, Portuguese and Spanish. No exclusion criteria were applied for the period or type of material.

\section{Theoretical frame of reference}

\subsection{Green Chemistry: emergence, definition and principles}

According to the American Chemistry Society (ACS) (2019), until the 1980's, the chemical industry and the United States Environmental Protection Agency (USEPA) were mostly concerned with pollution control practices. Nevertheless, in 1990, the Pollution Prevent Act was approved, according to which the policy of the country should eliminate pollution by source reduction rather than by the treatment and disposal of pollutants (United States, 1990). This resulted in a change of regulatory policies for pollution control to policies aimed at pollution prevention (Anastas \& Warner, 1998).

Thus, the 1990s were marked by a paradigm shift among chemists, contributing to the consolidation of Green Chemistry as a legitimate scientific field (ACS, 2019). Green Chemistry can be considered a form of pollution prevention by offering a methodology for changing the intrinsic nature of a chemical product or process (Anastas \& Warner, 1998; ACS, 2019) so that it presents a lower risk to human health and the environment. According to the American Chemistry Society (ACS, 2019), Green 
Chemistry can be defined as the arrangement of processes and chemicals that reduces or eliminates the use or generation of hazardous substances, considering the entire life cycle of a product, including its design, production, use and final disposal. Green Chemistry aims to prevent pollution at the molecular level, reduce the use of natural resources and reduce or eliminate the hazards of existing products and processes.

In 1998, Paul Anastas and John Warner published the Twelve Principles of Green Chemistry (Table 1), which concern chemical and environmental characteristics of products or processes (Anastas $\&$ Warner, 1998). The chemical characteristics refer to the need for chemical syntheses to be simple, one single step, present $100 \%$ yield, aim at atomic efficiency, be safe and eliminate waste. The environmental characteristics are related to reduction of pollutants and waste production, generation of non-toxic products, use of renewable reagents and consideration of environmental factors in chemical synthesis (Machado, 2011).

\subsection{Definitions of cosmetics}

It is possible to consider a general definition of cosmetics based on the purpose of these products and differentiate conventional cosmetics from green ones by their composition and production process.

TABLE 1 - Twelve principles of Green Chemistry.

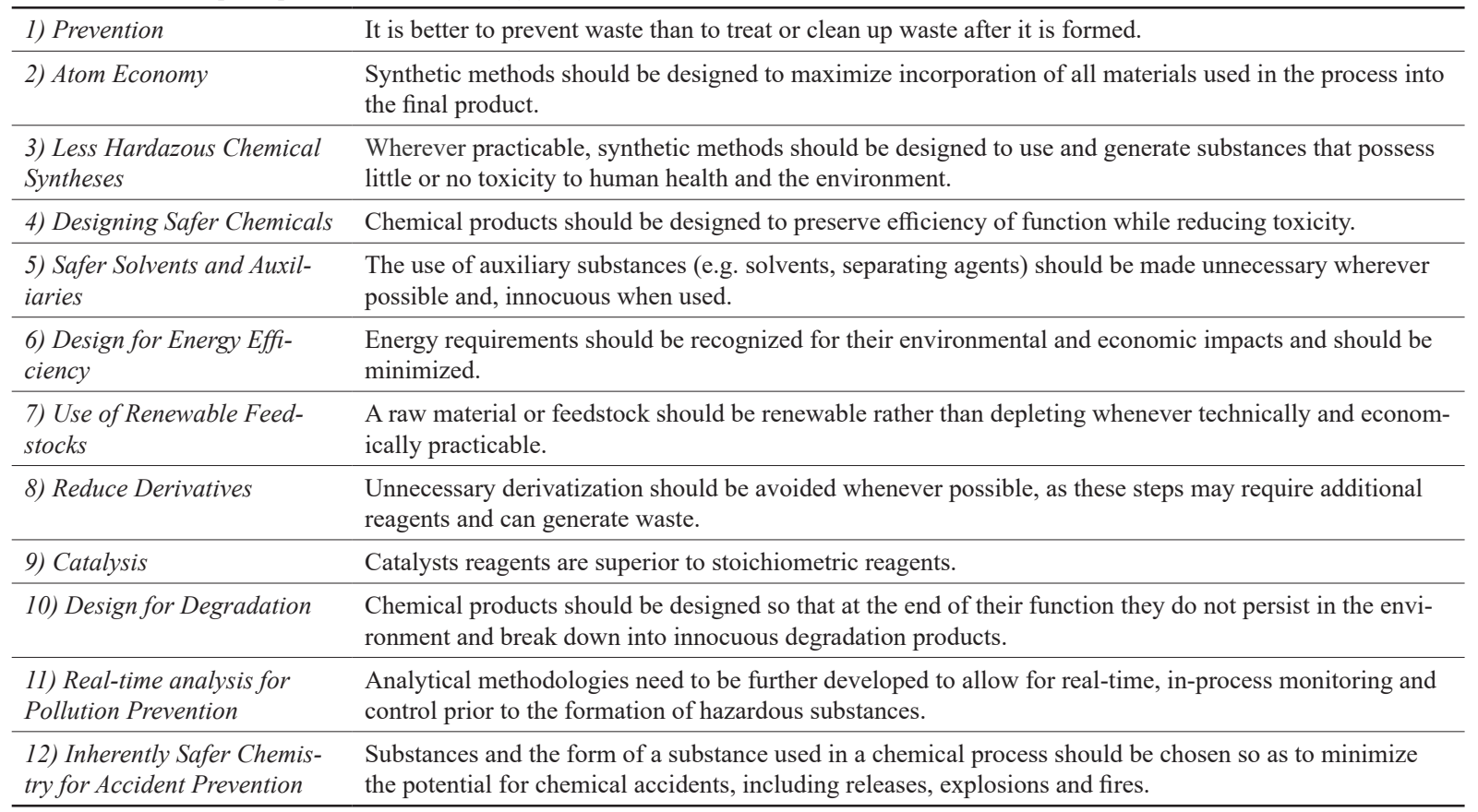

SOURCE: Anastas \& Warner (1998). 
Next, we will explore the definitions of conventional cosmetics adopted by government regulatory agencies in the United States, the European Union and Brazil.

In the United States, the Federal Food, Drug and Cosmetic Act of the United States Food and Drug Administration (USFDA) defines cosmetics as

(1) articles intended to be rubbed, poured, sprinkled, or sprayed on, introduced into, or otherwise applied to the human body for cleansing, beautifying, promoting attractiveness, or altering the appearance (United States, 2002).

According to European Directive no. $1223 / 2009$, a cosmetic product can be defined

as any substance or mixture intended to be placed in contact with the external parts of the human body (epidermis, hair system, nails, lips and external genital organs) or with the teeth and mucous membranes of the oral cavity with a view exclusively or mainly to cleaning them, perfuming them, changing their appearance, protecting them, keeping them in good condition or correcting body odours (European Union, 2009, p. 64).

In Brazil, the Agência Nacional de Vigilância Sanitária (Anvisa) - Portuguese for the Brazilian Health Regulatory Agency -, through RDC no. 7 of 2015, establishes the definition on personal hygiene products, cosmetics and perfumes

as preparations consisting of natural or synthetic substances, for external use in the various parts of the human body $[\ldots]$ with the sole or main purpose of cleaning them, perfuming them, changing their appearance and/ or correcting body odors and/or protecting them or keeping them in good condition (Brasil, 2015).

In the definitions of cosmetics presented above, it is possible to state that this category includes products intended to improve appearance (e.g. make-up), but also basic hygiene products such as shampoos, toothpaste and deodorants, as well as specific products for some health problems (anti-acne creams, anti-inflammatory lotions, anti-lice shampoos, etc.).

The governmental definitions previously presented also apply to green cosmetics. However, specific definitions and regulations are required to ensure compliance with certain production principles to differentiate these products from conventional cosmetics.

\subsection{Adverse effects caused by cosmetics: drivers for the application of Green Chemistry to cosmetology}

Scientific evidences of some adverse effects caused by conventional cosmetics and uncertainties about other effects have largely boosted demand for green cosmetics. Some examples of these potential adverse effects on human health are: allergic contact dermatitis caused by fragrances and preservatives (Hamilton \& De Gannes, 2011), and toxicity caused by heavy metals present in cosmetics (Borowska \& Brzóska, 2015). Nevertheless, there are also at least one example of indefiniteness (Darbre, 2009¹) and

\footnotetext{
${ }^{1}$ According to Darbre (2009), the proposed link between breast cancer and the use of cosmetic chemicals with oestrogenic and/or genotoxic properties provides an evidence-based hypothesis capable of further testing, since it is necessary to investigate the effects of long-term usage of mixtures of these chemicals over an entire lifetime.
} 
two of no or negligible risk (Nohynek et al., 2004; Witorsch, 2014³).

The scientific community has also been alerting to the presence of persistent substances with bioaccumulation potential and bioactivity used in large quantities in personal care products. In addition, UV filters, antiseptics and fragrances used in cosmetics may potentially undergo biomagnification at higher trophic levels in the aquatic environment when dumped through the sewage (Peck, 2006; Brausch \& Rand, 2011).

Ethical considerations that stressed the negative aspects of the cosmetics industry are also noteworthy, having boosted the movement towards the incorporation of the precepts of Green Chemistry to these products. These ethical considerations refer to the use of animals by the cosmetics industry in experiments to assess the safety of ingredients and final products, the overexploitation of natural resources and the generation of environmental pollution in the production, use and disposal of cosmetics (Sahota, 2014).

Considering that Green Chemistry is a philosophy that can be applied in all areas of Chemistry (United States, 2019) and has practical applications in industry (Anastas \& Eghbali, 2010), Cosmetology, i.e. the production and development of cosmeti$\mathrm{cs}$, is a potential area for applying the concepts and principles of Green Chemistry. Moreover, cosmetics and personal care products are one of the product categories in which the Twelve Principles of Green Chemistry, especially those related to toxicity reduction, can be applied, as they have great contact with users and should be as safe as possible (Cannon \& Warner, 2009).

Thereby, recently, there has been a trend towards applying the concepts and principles of Green Chemistry to cosmetics, producing the green cosmetics. However, it is necessary to analyze possible conceptual, regulatory and risk assessment gaps for these products, which will be addressed in the following sections.

\section{Results and discussion}

In Scopus ${ }^{\circledR}$ database, we found 52 papers on green, organic or natural cosmetics in October 2018. Out of this total, 12 are described as belonging to the area of Chemistry. Five articles address the existence of standards for natural and organic cosmetics and only 2 address certification systems of such products.

Considering the few number of articles related to conceptual, regulatory and risk assessment issues of green cosmetics, we focused mainly on the information obtained through the standards and technical guides of certification systems.

\subsection{Green cosmetics: what does it mean?}

Although the term "green" has a strong appeal in the cosmetics market, there is still no exact definition of what it in fact means. The most intuitive meaning of this term is its association with "environmentally friendly" and with the use of organic/ natural components (Leja \& Ross-Fichter, 2014).

\footnotetext{
${ }^{2}$ When commercial dyes were tested under their conditions of use, the results of human and animal studies revealed no evidence of systemic, genetic and reproductive toxicity or carcinogenic potential, representing no or negligible risk to human health (Nohynek et al., 2004).

${ }^{3}$ According to Witorsch (2014), on the basis of this analysis of the literature, it is concluded that triclosan does not present a risk of endocrine disruptive health effects through exposure to personal care products.
} 
The term "organic" is also not defined by the FDA regulations on cosmetics, as well as the term "natural" (United States, 2002). The European Directive No 1223/2009, which defines conventional cosmetics, does not present references to organic or natural cosmetics as well (European Union, 2009). The same occurs in Brazil (Freitas, 2014; Brasil, 2015).

In order to address this conceptual gap regarding the lack of government definitions of green/organic/ natural cosmetics, nongovernmental standards have emerged to ensure the differential characteristics of green cosmetics. One example are the voluntary certification systems.

Certification systems verify the ingredients, processes, production, storage of raw materials, packaging, labeling, energy use, waste management and labeling of producers, ensuring the quality of the final product. Certified products have some advantages over others, including the control and track of the raw material supply chain, increased confidence in the product brand, recognition and differentiation of the product in the market (Fonseca-Santos et al., 2015). Some examples of green cosmetic certification systems and their countries of origin are: BDIH (Germany), Ecocert (France), IBD (Brazil), ICEA (Italy) and Natrue (Belgium). Each of these systems establishes requirements for a cosmetic to be considered organic and/or natural. This can be considered an attempt to establish definitions for these products.

Some certification systems analyzed clearly state in their guidelines that, for a cosmetic to be considered green, it is necessary to follow the concepts and principles of Green Chemistry. ICEA, for example, explicitly determines the use of naturally occurring chemicals or derived from Green Chemistry (ICEA, 2019a). Other certification systems, however, do not comply with the principles of Green Chemistry (Ecocert, 2012; IBD, 2014; BDIH, 2019a; Natrue, 2019b).

Cosmos-Standard, a standard created in conjunction with five certification agencies in Europe - BDIH, Cosmebio, Ecocert, ICEA and Soil Association - aimed at harmonizing their guidelines - states that some of the rules to be adopted by companies certified is to integrate and develop the concept of "Green Chemistry" using organic agricultural products and clean manufacturing processes (Cosmos-Standard, 2019b).

In general, most definitions of organic cosmetics adopted by the certification systems analyzed set percentages for the minimum content of organic ingredients or from organic certified farms. In the case of natural cosmetics, minimum percentages of natural substances or botanical ingredients and maximum content of synthetic or natural derived substances are determined. However, these percentages vary widely between different certification systems, types of labels and even types of products, since in some cases the minimum content of organic/natural ingredients is established according to the product.

The minimum percentage of natural ingredients, for example, ranges from $15 \%$ for IBD's "natural cosmetics with organic portions" label to $95 \%$ for Ecocert's "natural cosmetic" label. It allows certain products to be certified as organic or natural by some certification systems and not by others, making it difficult for consumers to understand green certificates and the differences among them.

Fonseca-Santos et al. (2015) reaffirm this lack of harmonization between the guidelines of green cosmetic certification systems, which can create conceptual barriers to the diffusion of these products. The Table 2 depicts the general guidelines of the certification systems. 
TABLE 2 - Main organic/natural cosmetic certification systems, their scopes (types of products/services) and their requirements for a cosmetic to be considered organic/natural.

\begin{tabular}{|c|c|c|}
\hline $\begin{array}{l}\text { Certification } \\
\text { system/country, } \\
\text { year of creation }\end{array}$ & Scope & Requirements for granting certification (by type of label) \\
\hline $\begin{array}{l}\text { BDIH } \\
\text { Germany, } 1996 \\
\text { (BDIH, 2019a; } \\
\text { 2019b) }\end{array}$ & Natural Cosmetics & $\begin{array}{l}\text { Use natural raw materials from controlled biological cultivation or controlled biological } \\
\text { wild collection, if possible, certified; } \\
\text { Raw materials of plant origin must originate from certified organic raw material. }\end{array}$ \\
\hline
\end{tabular}

Natural cosmetics:

- For multi-ingredient products: a product can be certified if it is made with water and uncertified natural ingredients, or ingredients allowed for natural formulations. The percentage by weight depends on the kind of product:

- $\quad$ Vegetable juices: $100 \%$ natural

- Concentrated vegetable juices: only $100 \%$ concentrated (as a Natural), not the water used for dilution

- Aqueous extracts: only one vegetable portion

- Hydro-alcoholic extracts: the plant and alcoholic portions (if it is a natural substance).

- For raw material: Raw material / ingredient can only be classified and certified as

Organic products (cattle

IBD

Brasil, 1982

(CI Orgânicos,

2015; IBD,

2014; IBD,

2019) raising, agricultural production, cosmetics production, production of inputs, production of raw materials for cosmetics, textile production, restaurants, hotels, forestry) "natural" if it is in accordance with the above, if the reaction of obtaining the product is authorized and if the preservative used is on the List of Materials Authorized by IBD. Natural cosmetics with organic portion:

-For multi-ingredient products:

- $\quad \geq 15 \%$ natural non-modified substances;

- $\quad \leq 15 \%$ natural derived substances;

- $\quad \geq 70 \%$ natural substances of animal and vegetable origin and natural derived substances should come from organic controlled management and/or extractivism. - For raw material: raw material/ingredient can only be classified and certified as "made with organic ingredient" if it is in accordance with the above, if the reaction product is authorized and if the preservative used is on IBD's List of Authorized Materials.

Organic cosmetics:

- For multi-ingredient product:

- Follow the requirements for natural cosmetics with organic portion;

- $\quad \geq 20 \%$ natural non-modified substances;

- $\quad \leq 15 \%$ natural derived substances

- $\quad \geq 95 \%$ natural substances of animal and vegetal origin and natural derived substances should come from organic controlled management and/or extractivism. - For raw material: raw material/ingredient can only be certified as "made with organic ingredient" if it is in accordance with the above, if the reaction product is authorized and if the preservative used is on IBD's List of Authorized Materials. 
ICEA

Italy, not informed

(Istituto per la

Certificazione

Etica e Ambi-

entale (ICEA,

2019a; 2019b))
Food, cosmetics and detergents, textiles, sustainable tourism, buildings, recycled products, social responsibility

\section{Eco Bio Label:}

The products "ICEA Eco Bio Cosmetics" are cosmetics or other similar products with the same functions and characteristics even if destined to animals, obtained in compliance with the "ICEA Environment-friendly Cosmetics" Standard and in particular without the use of genetically modified organisms; without the use of ionizing radiations; with the use of certified organic vegetable and animal raw materials; with the use of chemical substances from natural origin or derived from Green Chemistry, selected under the criteria of environment sustainability and salubriousness. Other requirements are:

- $\quad$ Plant raw materials of organic certified agriculture;

- $\quad$ Raw materials derived or produced from animals should be certified as organics and included in the list of ingredients

Natural cosmetics:

The ICEA "Natural Cosmetics" products are cosmetics or other similar products with the same functions and characteristics even if destined to animals, obtained in compliance with the "Natural Cosmetics" Standard and in particular without the use of genetically modified organisms; without the use of ionizing radiations; with the use of chemical substances from natural origin or derived from Green Chemistry, selected under the criteria of environment sustainability and salubriousness. The use of organic raw materials is not mandatory, but if used, should be reported in the product description on the label and in the list of ingredients.

\section{Natural cosmetics:}

The minimum content of natural substances and the maximum of natural derived substances vary according to the type of product. Some examples are presented below:

- $\quad$ Parfum/Eaux de parfum, cologne or toilette $=\geq 60 \%$ natural substances and $\leq 10 \%$ derived natural substances;

- $\quad$ Skin care emulsions and oleogels $=\geq 30 \%$ natural substances and $\leq 30 \%$ derived natural substances;

- $\quad$ Deodorants/antiperspirants $=\geq 10 \%$ natural substances and $\leq 30 \%$ derived natural substances;

- $\quad$ Sunscreens $=\geq 10 \%$ natural substances and $\leq 55 \%$ derived natural substances;

- Hair treatment products $=\geq 3 \%$ natural substances and $\leq 40 \%$ derived natural substances;

- $\quad$ Oral care $=\geq 2 \%$ natural substances and $\leq 70 \%$ derived natural substances Natural cosmetics with organic portion:

- Follow the requirements for natural cosmetics cosmetic, at the same or higher level of exigence;

- $\quad \geq 70 \%$ natural substances of animal and vegetable origin and natural derived substances should come from controlled organic farming and/or certified wild collection. Organic cosmetics:

- Follow the requirements for natural cosmetics and natural cosmetics with organic portion, at the same or higher level of exigence;

- $\quad \geq 95 \%$ natural substances of animal and vegetable origin and natural derived substances should come from controlled organic farming and/or certified wild collection.

Natural cosmetics:

Cosmos Stan-

dard

Belgium, 2010

(Cosmos

Standard, 2019a;

Organic or natural cosmetics
There are no requirements on the use of minimal amounts of organic ingredients. Organic cosmetics:

- $\quad \geq 95 \%$ organic ingredients;

- $\quad \geq 20 \%$ all ingredients should be organic;

- $\quad$ Exceptionally, for products to be rinsed, for non-emulsified aqueous products and for those with at least $80 \%$ of minerals or mineral ingredients, $\geq 10 \%$ of all ingredients should be organic. 
In an attempt to overcome the conceptual barriers to the definition of green cosmetics derived from the lack of harmonization between the guidelines of the certification systems, Cosmos Standard is an initiative to consolidate a standard procedure for the certification of organic/natural cosmetics in Europe (Cosmos-Standard, 2019a). This kind of initiatives can help to establish a more precise and standardized definition for green cosmetics, facilitating the interpretation of green certificates by consumers. However, it is important that this harmonization can be expanded to reach greater scales of influence, in order to contribute to the overall standardization of green cosmetic guidelines.

\subsection{Regulations of green cosmetics}

The lack of definitions of organic and natural cosmetics discussed in the previous section hampers the emergence of specific government definitions on these products. Likewise, green certification systems analyzed have established restrictions and regulations so that these products can be certified as organic/ natural.

The voluntary certification of organic/natural cosmetics firstly requires compliance with regulations regarding conventional cosmetics in the country, which means that these systems require the fulfillment of requirements that go beyond those determined by law, differentiating conventional and green cosmetics.

The verification of compliance with these regulations by certified products is made through periodic audits performed by accredited independent certification agencies (third party audits). In these audits, auditors verify product and process control, corrective and preventive actions carried out, product traceability, claims made against the company and aspects such as the storage and packaging of the product, as well as the relevant documentation. In addition, laboratory tests may be carried out on samples of products in order to evaluate their compliance with the guidelines of the standard (IBD, 2014; BDIH, 2019a; Cosmos-Standard, 2019b; Ecocert, 2019b; ICEA, 2019a; Natrue, 2019b).

In general, most certification systems establish regulations regarding animal welfare, including the prohibition of animal testing and the restriction of the use of materials obtained from dead animals. In addition, all the certification systems present restrictions on the ingredients used in the production of cosmetics, some of which also restrict production processes. Another frequent restriction is the ban on the use of genetically modified organisms (GMO) and the treatment of the final product and the raw materials with ionizing radiation. The restriction of ingredients, processes and GMO can be interpreted as an attempt of reducing toxicity to human and environmental health, as stated by the principles of Green Chemistry.

As much as identified in this work, Cosmos-Standard is the only system that, in addition to making explicit mention to Green Chemistry, sets out indicators to verify that certified products are in fact complying with some of the Twelve Principles, such as calculating the atomic economy of cosmetic production reactions, establishing minimum aquatic toxicity and biodegradability requirements for ingredients used and produced and the prohibition of the use and generation of bioaccumulative and non-biodegradable substances. However, this certification system claims that, in the current state of development of Green Chemistry, it is not yet possible to specify limits or requirements for all principles. (Cosmos-Standard, 2019b). 
TABLE 3 - Regulations of organic and/or natural cosmetics established by each certification system.

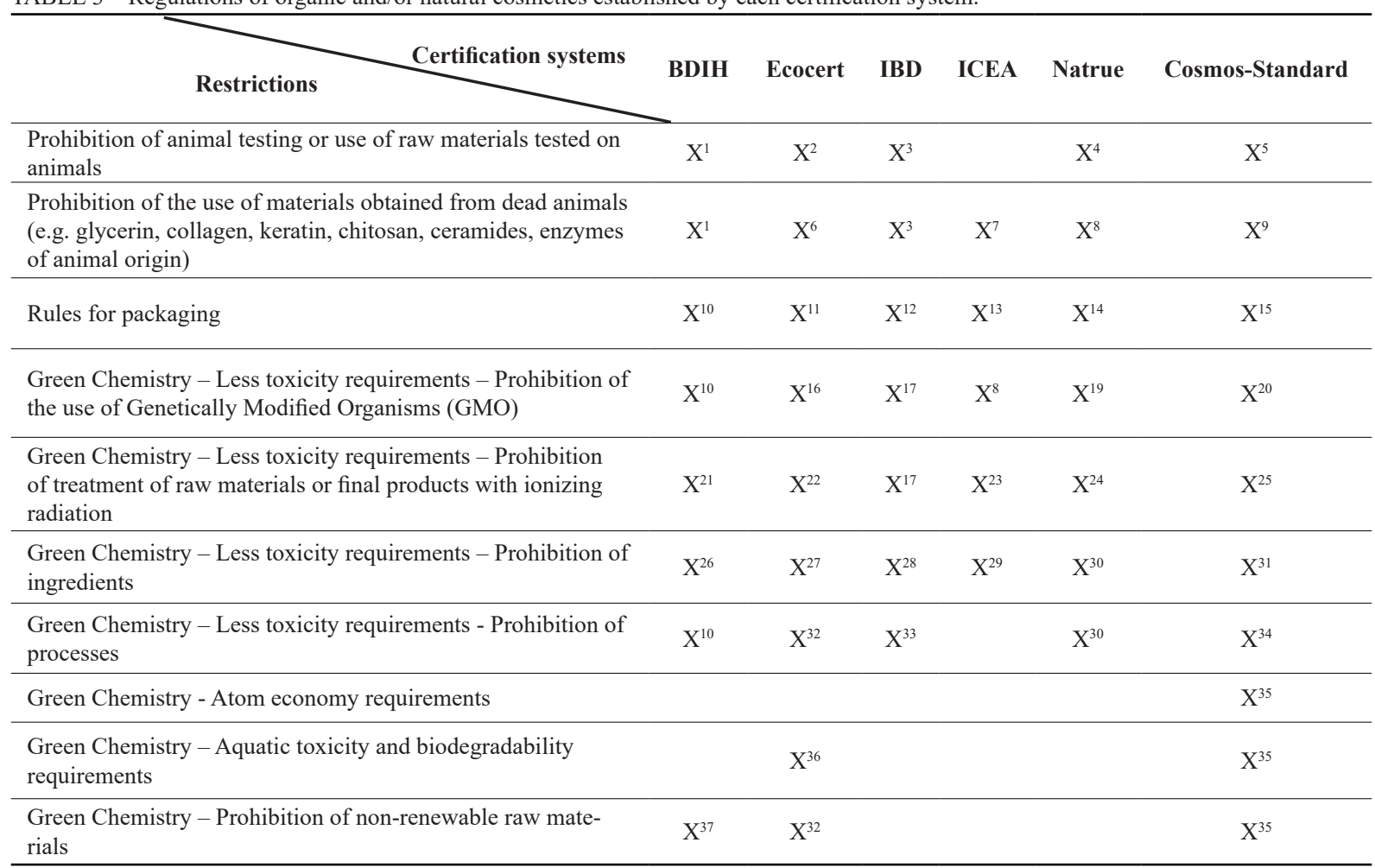

${ }^{1}$ BDIH, 2019a, section "2. Animal protection", p. 1.

${ }^{2}$ Ecocert, 2012, section "5. Animal testing of the finished products", p. 21.

${ }^{3}$ IBD, 2014, section "5 - Proteção animal e testes em animais", p. 3.

${ }^{4}$ Natrue, 2019b; section “1.2.1 Cosmetics Products: Regulation (EC) No 1223/2009”, p. 1.

${ }^{5}$ Cosmos-Standard, 2019b; section "5.2 - Animal testing", p. 9.

${ }^{6}$ Ecocert, 2012, section “d) Animal ingredient and ingredient from animal origin”, p. 18 (Ecocert, 2012).

${ }^{7}$ ICEA, 2019a; section "6.3 Animal raw materials", p. 5.

${ }^{8}$ Natrue, 2019b; section "2.1 - Natural substances”, p. 3.

${ }^{9}$ Cosmos-Standard, 2019b, section "6.1.3 - Physically processed agro-ingredients", p. 11.

${ }^{10}$ BDIH, 2019a, section "Further goals", p. 3.

${ }^{11}$ Ecocert, 2012, section "V - Conditioning and packaging", p.22.

${ }^{12}$ IBD, 2014, section "5 - Embalagens", p. 12.

${ }^{13}$ ICEA, 2019a, section "6.8 Packaging”, p. 6.

${ }^{14}$ Natrue, 2019b; section " 5 . Requirements to be met by packaging and packaging materials", p. 7

${ }^{15}$ Cosmos-Standard, 2019b, section "8. Storage, manufacturing and packaging", p. 19.

${ }^{16}$ Ecocert, 2012, section “5. Biotechnological processed ingredient”, p. 19

${ }^{17}$ IBD, 2014, section "7 - Ingredientes proibidos", p. 7.

${ }^{18}$ ICEA, 2019a, section “6 - Genetically Modified Organisms”, p. 6. 
${ }^{19}$ Natrue, 2019b; section “1.2.3 Prohibition on the use of Genetically Modified Organisms (GMOs)”, p. 2.

${ }^{20}$ Cosmos-Standard, 2019b; section "5.1.2 Genetically modified organisms (GMOs)", p. 9. 21BDIH, 2019a, section "7 - No radioactive radiation", p. 2.

${ }^{22}$ Ecocert, 2012, section "List of authorized and forbidden processes", p. 35.

${ }^{23}$ ICEA, 2019a, section "6.7 Irradiation”, p. 6.

${ }^{24}$ Natrue, 2019b; section "2.1 - Natural substances", p. 4.

${ }^{25}$ Cosmos-Standard, 2019b; section "5.1.3 Irradiation”, p. 9.

${ }^{26}$ BDIH, 2019a, section "5. Deliberate rejection of", p. 2.

${ }^{27}$ Ecocert, 2012, section "Positive list of authorized synthetic ingredients and ingredients from mineral origin”, p. 36.

${ }^{28}$ IBD, 2014, section "7 - Ingredientes proibidos", p. 7.

${ }^{29}$ ICEA, 2019a; section “Annex 1 - List of substances to NOT use to obtained the certified brand ICEA Organic Cosmetics”, p. 10.

${ }^{30}$ Natrue, 2019b; section “2. Definition of permitted ingredients and processes”, p. 3.

${ }^{31}$ Cosmos-Standard, 2019b; section “11.2 - Approval of ingredients”, p. 26.

${ }^{32}$ Ecocert, 2012, section “Appendix I: Validation criteria for processes used to obtain ingredients”, p. 29.

${ }^{33}$ IBD, 2014, section "6 - Processos de obtenção de ingredientes”, p. 3.

${ }^{34}$ Cosmos-Standard, 2019b; section “Appendix III: examples of processes not allowed”, p. 33.

${ }^{35}$ Cosmos-Standard, 2019b; section "6. Ingredients categories", p. 12.

${ }^{36}$ Ecocert, 2012, section "3. The biodegradability and ecotoxicity of ingredients", p. 30.

${ }^{37}$ BDIH, 2019a, section “Transparency for the consumer", p. 1.

Based on the analysis of certification systems guidelines, it is possible to verify significant variations between the types of regulations established. Certain restrictions are adopted by some agencies and not by others. These differences can be observed in Table 3, which depicts the regulations of certification systems concerning green cosmetics, including restrictions linked to the Principles of Green Chemistry.

Likewise, attempts to harmonize certification systems globally also become relevant, allowing greater equality between the requirements followed by certified products and enhancing restrictions linked to the Principles of Green Chemistry.

\subsection{Risk assessment applied to green cosmetics}

Risk assessment refers to the use of a factual basis to define the health effects to individuals or populations caused by the exposure to materials and hazardous situations, involving epidemiological, clinical, toxicological and environmental studies (RiskCom, 2018).

The chemical composition of cosmetics, both conventional and organic/natural, may include additives or toxic impurities, which reveals the need of development and application of risk assessment models for both classes of products.

\subsubsection{Prospects for replacing harmful ingredients in green cosmetics}

Red lists are checklists of chemicals whose use is not recommended because of their possible hazards. Some ingredients or impurities most 
commonly mentioned by red lists of different institutions are: 1,4-dioxane; coal tar; BHA (butylated hydroxyanisol)/BHT (butylated hydroxytoluene); formaldehyde and formaldehyde releaser preservatives; ethanolamine compounds; hydroquinone; lead and heavy metals; microbeads; nanoparticles; nitrosamines; parabens; petrolates; phthalates; silicones and triclosan (UL, 2015). Certification systems analyzed incorporate restrictions to several of the compounds present in red lists, aiming at reduce risks to the environment and human health, as one can see for silicones (IBD, section "7. Forbidden ingredients", p. 7), formaldehyde (Ecocert, 2012, section "2. Restricted substances", p. 32) and nanoparticles (Cosmos-Standard, 2019b, section "5.1.1 Nanomaterials", p. 9; Ecocert, 2012, section "1. Nanoparticular ingredients", p. 18).

In exchange, natural and botanical products or waste products derived from agriculture, food and beverages can be used in cosmetic formulations, performing various types of functions (Fonseca-Santos et al. 2015) and may substitute hazardous ingredients present in red lists, as it will be presented next.

Some examples of the potential use of natural compounds as cosmetic ingredients are the grapevine pulp muscadine (Vitis rotundifolia Michx 1803) and cassis juice (Ribes nigrum L. 1753) in topical applications of cosmetics to avoid skin hyperpigmentation (Plundrich et al., 2013) and the use of green coffee oil (Coffea canephora Pierre ex Froehn. 1897) in formulations of sunscreens, increasing the sun protection factor and performing satisfactory antioxidant activity (Chiari et al., 2014). Besides that, there are studies that show the increase of skin hydration after two weeks of use of formulations containing different concentrations of freeze-dried aloe vera (Aloe vera (L., 1753) Burm.f, 1768) extracts (Dal'Belo et al., 2006).

Additionally, it has been demonstrated that essential oils in the examined concentrations show higher inhibitory activity against bacteria and yeasts compared with methylparaben, the main preservative used in conventional cosmetics (Herman et al., 2013). Thus, mixtures of different essential oils and extracts may be effective in inhibiting the growth of a broad spectrum of microorganisms and replacing or reducing the amount of synthetic preservatives added to cosmetics

The scientific studies mentioned demonstrate that various types of natural ingredients may be used in cosmetics to replace the use of possibly harmful substances. However, such studies should evaluate the efficacy of these substitutes in cosmetic formulations, interacting with other ingredients, ensuring that they perform the functions for which they are assigned.

Other possibility is reducing the expiration period of cosmetic products as an alternative for minimizing the exposure to preservatives both synthetic and natural. By making expiration periods more compatible with product package volumes, it would be possible to reduce the risk of adverse effects from the use of these substances.

\subsubsection{Safety of substitute ingredients in green cosmetics}

Despite the existence of significant scientific literature on the potential of using natural or botanical ingredients in cosmetic formulations, it is necessary to develop appropriate approaches for the risk assessment of these ingredients. 
Excessive reliance on the red lists of hazardous ingredients in cosmetics may lead many manufacturers to substitute potentially hazardous compounds for substances whose potential health and safety effects are not yet well established (UL, 2015).

In addition, the increasing number and complexity of organic and natural cosmetic ingredients and the lack of internationally harmonized standards may result in the emergence of products that lack quality and/or safety acceptable standards. It is also important to highlight the absence of approaches to assess benefits or safety of botanical ingredients. Being natural does not always mean a lack of toxicity or risks to human health. Plants or botanical products may contain potential contaminants, irritants, allergens, phototoxic or photoallergenic substances or allergens when used in cosmetic formulations (Antignac et al., 2011).

Thereby, despite the popular belief in the innocuousness of natural ingredients, there are several reports of adverse reactions to plant extracts, in particular cutaneous effects, such as allergic contact dermatitis, irritative contact dermatitis, phototoxic reactions and contact urticaria. (Fonseca-Santos et al. 2015) ${ }^{4}$. These effects can be explained by the complexity of botanical ingredients, natural variability between populations and lineages, seasonal, cyclical or irregular fluctuations in the production of the compound by the plant, production of potentially toxic substances, interactions with human drugs, presence of heavy metals, incorrect identification of plants, adulteration with active substances of medicinal products or with other plant species and improper preparation or processing of the products (Antignac et al., 2011). Although these factors do not always justify the occurrence of adverse effects, they should be properly addressed during selection, preparation and use of botanical ingredients to ensure their safe use.

Among the 1,358 natural substances listed in the International Nomenclature of Cosmetics Ingredients (INCI), 38\% are classified as hazardous to human health, causing skin irritation, severe eye damage and irritation or respiratory difficulty. In addition, 53 natural substances on the INCI list are classified as carcinogenic, mutagenic and toxic for reproduction (Klaschka, 2015).

According to Antignac (2011), the risk or safety assessment of plant-derived ingredients should involve the characterization of the plant and its origin and the chemical characterization of the ingredient to be used. It is also necessary to compare the material under analysis with others that have a history of safe human use. It is recommended that the risk assessment preferably uses tests performed by the skin route, avoiding the uncertainties of the extrapolation of results between different exposure routes and include analysis of local and systemic effects. In addition, it is important to verify the natural variability of plant strata. Finally, the risk assessment of botanical ingredients should be aligned with the current safety assessment paradigm and should have a system to control chemical and biological contamination during the production chain of these ingredients.

\footnotetext{
${ }^{4}$ Fonseca-Santos et al. (2015) cite: Ernst, E. Adverse effects of herbal drugs in dermatology. Brit. J. Dermatol., 143(5), 923-929, 2000.; Simpson, E. L.; Law, S. V.; Storrs, F. J. Prevalence of botanical extract allergy in patients with contact dermatitis. Dermatitis, 15(2), 67-72, 2004.; e Corazza, M. et al.. Topical botanically derived products: use, skin reactions, and usefulness of patch tests: a multicentre Italian study. Contact Dermatitis, 70(2), 90-97, 2014.
} 
Thereby, the choice of plant extracts should be based on the confirmation of their biological activity and toxicological evaluation. Their stability and possible synergistic effects in cosmetic formulations should also be considered (Fonseca-Santos et al., 2015).

In addition, there are many natural substances that are not easily degradable in the environment and their use in cosmetic products implies a great dispersive use and a continuous discharge, which can generate impacts to the aquatic environment and the organisms that inhabit it. Among the 1,358 INCI natural substances, 185 (28\%) are classified as hazardous to the aquatic environment (Klaschka, 2015). It demonstrates the need for ecotoxicological studies for these components, as well as the improvement of legal requirements about them (Klaschka, 2016), aiming at following properly the principles of Green Chemistry that state about reducing toxicity.

\section{Conclusion}

Green cosmetics represent a perspective of reducing the risks to human health and the environmental impacts caused by cosmetics. However, there are conceptual, regulatory and risk-related limitations to its development and diffusion.

From conceptual and regulatory perspectives, the lack of government definitions and regulations on organic/natural cosmetics in many countries highlights the need to establish specific definitions and regulations by governmental and nongovernmental bodies, such as green cosmetic certification systems. However, the existence of many agencies and certification systems and different types of labels can create confusion for the general public and even discredit green certificates. Thereby, it is important that the guidelines adopted by these systems are standardized and fulfill their role in ensuring compliance by the companies and in communicating consumers properly.

Regarding the compliance with Green Chemistry, most certification systems do not state in their guidelines the following of the concepts and principles of Green Chemistry explicitly, although some systems incorporate some of these principles into their own guidelines. As an example, Cosmos-Standard sets out indicators to verify that certified products are meeting some of the Twelve Principles of Green Chemistry, such as the atomic economy of cosmetic production reactions, the establishment of minimum aquatic toxicity and biodegradability requirements for ingredients used and produced and the prohibition of the use and generation of bioaccumulative and non-biodegradable substances. However, in the state of development of Green Chemistry as in 2013, it was not yet possible to specify limits or requirements for all principles.

The prospects for the risk analysis of green cosmetics include the existence of studies demonstrating the possibility of using natural ingredients with different functions instead of synthetic ingredients known to be harmful to human and environmental health. However, the use of alternative ingredients, including those of vegetable origin, in green cosmetics requires reliable tests to verify their efficacy in cosmetic formulation, careful risk/ safety analyses, ecotoxicological studies on the effects of these substances on other organisms in the environment and compliance with the principles of Green Chemistry.

From this effort to analyze the state of the art of green cosmetics and place them in the context of 
Green Chemistry, the paper contributes to provide a current and compiled overview of theoretical aspects that can subsidize future decision making to promote progressive incorporation of concepts and principles of Green Chemistry into the overcoming of conceptual, regulatory and risk assessment limitations of green cosmetics.

\section{References}

ACS - American Chemical Society. ACS Green Chemistry Institute. Green Chemistry History, 2019. Available from: $<$ https://www.acs.org/content/acs/en/greenchemistry/ what-is-green-chemistry/history-of-green-chemistry.html $>$. Access on: Oct. 11, 2019.

Anastas, P.; Eghbali, N. Green chemistry: principles and practice. Chemical Society Reviews, 39(1), 301-312, 2010. doi: 10.1039/B918763B

Anastas, P. T.; Warner, J. C. Green chemistry: theory and practice. New York: Oxford University Press, 1998.

Antignac, E.; Nohynek, G. J.; Re, T.; Clouzeau, J.; Toutain, $\mathrm{H}$. Safety of botanical ingredients in personal care products/ cosmetics. Food and Chemical Toxicology, 49(2), 324-341, 2011. doi: 10.1016/j.fct.2010.11.022

BDIH - Bundesverband der Industrie- und Handelsunternehmen. BDIH guidelines for certified natural cosmetics. Available at: <http://www.makingcosmetics.com/articles/ BDIH-Guidelines-for-Certified-Natural-Cosmetics.pdf $>$. Access on: Oct., 2019a.

BDIH - Bundesverband der Industrie- und Handelsunternehmen. Transparency for the consumer. Available at: $<$ https://www.kontrollierte-naturkosmetik.de/e/guideline natural_cosmetics.htm>. Access on: Oct., 2019b.

Borowska, S.; Brzóska, M. M. Metals in cosmetics: implications for human health. Journal of Applied Toxicology, 35(6), 551-572, 2015. doi: 10.1002/jat.3129

Brasil. Resolução Anvisa RDC no 7, de 10 de fevereiro de 2015. Dispõe sobre os requisitos técnicos para a regulariza- ção de produtos de higiene pessoal, cosméticos e perfumes e dá outras providências. Brasília: DOU of 2/11/2015.

Brausch, J. M.; Rand, G. M. A review of personal care products in the aquatic environment: environmental concentrations and toxicity. Chemosphere, 82(11), 1518-1532, 2011. doi: 10.1016/j.chemosphere.2010.11.018

Cannon, A.; Warner, J. Green chemistry: foundations in cosmetic sciences. In: Lintner, K. (Ed.). Global regulatory issues for the cosmetics industry. Norwich: William Andrew Inc., 2. ed., 2009. p. 1-16.

Chiari B. G.; Trovatti, E.; Pecoraro, E.; Corrêa, M. A.; Cicarelli, M. R. B.; Ribeiro, S. J. L.; Isaac, V. L. B. Synergistic effect of green coffee oil and synthetic sunscreen for health care application. Industrial Crops and Products, 52, 389393, 2014. doi: 10.1016/j.indcrop.2013.11.011

CI Orgânicos. Processo de certificação IBD, 2015. Available at: $<$ https://ciorganicos.com.br/biblioteca/processo-de-certificacao-ibd/>. Access on: Oct., 2019.

Cosmos-Standard. About us. Available at: <https://Cosmos-standard.org/about/>. Access on: Oct., 2019a.

Cosmos-Standard. Cosmetics organic and natural standard. Version 3.0, 2019b. Available at: < https://Cosmosstandard. files.wordpress.com/2018/12/Cosmos-standard-V3.0-including-editorial-changes-0101_2019.pdf $>$. Access on: Oct., 2019.

Dal'Belo, S. E.; Gaspar, L. R.; Campos, P. M. B. G. M. Moisturizing effect of cosmetic formulations containing Aloe vera extract in different concentrations assessed by skin bioengineering techniques. Skin Research and Technology, 12(2), 241-246, 2006. doi: 10.1111/j.0909752X.2006.00155.X

Darbre, P. D. Underarm antiperspirants/deodorants and breast cancer. Breast Cancer Research, 11, Suppl. 3, S5, 2009. doi: 10.1186/bcr2424

Ecocert. Ecocert Standard Natural and Organic cosmetics, v. 2, 2012. Available at: <https://Ecocert.app.box.com/v/ Ecocert-Standard $>$. Access on: Oct., 2019.

Ecocert. About us. Available at: <https://www.Ecocert.com/ en/about-us $>$. Access on: Oct., 2019a. 
Ecocert. Organic and natural products. Available at: $<$ http:// www.Ecocertico.com/organic-and-natural-cosmetics/index. html>. Access on: Oct., 2019b.

Ecocert. Our certifications. Available at: $<$ https://www.Ecocert.com/en-XX/certifications-list $>$. Access on: Oct., 2019c.

European Union. Regulation (EC) No 1223/2009 of the European Parliament and of the Council of 30 November 2009 on cosmetic products. Official Journal of the European Union of 12/22/09.

Fonseca-Santos, B.; Corrêa, M. A.; Chorilli, M. Sustainability, natural and organic cosmetics: consumer, products, efficacy, toxicological and regulatory considerations. Brazilian Journal of Pharmaceutical Sciences, 51(1), 2015. doi: 10.1590/S1984-82502015000100002

Freitas, T. Sem regulação, país é coadjuvante em cosméticos orgânicos, 2014. Available at: $<$ http://www1.folha.uol.com. br/mercado/2014/03/1429457-sem-norma-pais-e-coadjuvante-em-cosmeticos-organicos.shtml $>$. Access in: Oct., 2018.

Grand View Research. Organic personal care market size, share \& trends analysis report by application (cosmetics, skin care, oral, hair care), by region, and segment forecasts, 2019 - 2025. San Francisco: Grand View Research, 2019. Available at: <https://www.grandviewresearch.com/ industry-analysis/organic-personal-care-market>. Access on: Sept., 2019.

Hamilton, T.; De Gannes, G. C. Allergic contact dermatitis to preservatives and fragrances in cosmetics. Skin Therapy Letter, 16(4), 1-4, 2011. Available at: http://www.skintherapyletter.com/allergic-contact-dermatitis/cosmetics/

Herman, A.; Herman, A. P.; Domagaszka, B. W.; Mlynarczyk, A. Essential oils and herbal extracts as antimicrobial agents in cosmetic emulsion. Indian Journal of Microbiology, 53(2), 232-237, 2013. doi: 10.1007/s12088012-0329-0

IBD - Instituto Biodinâmico de Certificações. Diretrizes para a certificação de produtos de saúde e beleza orgânicos e naturais e para ingredientes orgânicos e naturais. 5. ed., 2014. Available at: <https://www.ibd.com.br/wp-content/uploads/2019/09/8_1_2_Diretrizes_IBD_Cosmeticos_5aEd_082014_V.pdf $>$. Access on: Oct., 2019.
IBD - Instituto Biodinâmico de Certificações. Certificações. Available at: <https://www.ibd.com.br/certificacoes/> Access on: Oct., 2019.

ICEA - Istituto per la Certificazione Etica e Ambientale. Organic and natural cosmetics certification rule. 4. ed., 2019a. Available at: <https://icea.bio/ wp-content/uploads/2017/01/2.-Regolamento-certificazione-3C.16en-Eco-Bio-Cosmesi-e-Cosmesi-Naturale-ICEA-Istituto-di-Certificazione-Etica-e-Ambientale. pdf>. Access on: Oct., 2019.

Istituto per la Certificazione Etica e Ambientale (ICEA). Non-Food. Available at: $<$ https://icea.bio/non-food/>. Access on: Oct., 2019b.

Klaschka, U. Naturally toxic: natural substances used in personal care products. Environmental Sciences Europe, 27(1), 1-12, 2015. doi: 10.1186/s12302-014-0033-2

Klaschka, U. Are natural compounds used in personal care products toxic for the aquatic environment? Sustainable Chemistry and Pharmacy, 4, 13-20, 2016. doi: 10.1016/j. scp.2016.07.002

Leja, P.; Ross-Fichtner, R. What green means for cosmetics, 2014. Available at: <http://www.cosmeticsandtoiletries. com/regulatory/organic/What-Green-Means-For-Cosmetics-premium-265533121.html?prodrefresh $=\mathrm{y}>$ Access in: Oct. 2018.

Łopaciuk, A.; Łoboda, M. Global industry trends in the $21^{\text {st }}$ century. In: Proceedings of International Conference of Management, Knowledge \& Learning. Zadar, Croatia, 1921 of Jun., 2013. Available at: <http://www.toknowpress.net/ ISBN/978-961-6914-02-4/papers/ML13-365.pdf>. Access on: Sept., 2019.

Machado, A. A. S. C. A síntese verde: (1) conceito e génese. Boletim da Sociedade Portuguesa de Química, II(120), 43-48, 2011. Available at: https://www.spq.pt/magazines/ BSPQuimica/650/article/30001621/pdf

Natrue. The international Natural and Organic Cosmetics Association. Who we are. Available at: $<\mathrm{https}: / / \mathrm{www}$.natrue. org/who-we-are/>. Access on: Oct., 2019a.

Natrue. The international Natural and Organic Cosmetics Association. Natrue Label: requirements to be met by nat- 
ural and organic cosmetics - Version 3.8, June 1, $2019 \mathrm{~b}$. Available at: <https://www.natrue.org/uploads/2019/06/ EN-Natrue-Label_Requirements_V3_8.pdf $>$. Access on: Oct., 2019.

Nohynek, G. J.; Fautz, R.; Benech-Kieffer, F.; Toutain, $\mathrm{H}$. Toxicity and human health risk of hair dyes. Food and Chemical Toxicology, 42(4), 517-543, 2004. doi: 10.1016/j. fct.2003.11.003

Peck, A. M. Analytical methods for the determination of persistent ingredients of personal care products in environmental matrices. Analytical and Bioanalytical Chemistry, 386(4), 907-939, 2006. doi: 10.1007/s00216-006-0728-3

Pike, H. Is natural beauty only skin deep?, 2015. Available at: <https://www.businessoffashion.com/articles/intelligence/natural-beauty-market-chemical-cosmetics $>$. Access on: Oct., 2019.

Plundrich, N.; Grace, M. H.; Raskin, I.; Lila, M. A. Bioactive polyphenols from muscadine grape and blackcurrant stably concentrated onto protein-rich matrices for topical applications. International Journal of Cosmetic Science, 35(4), 394-401, 2013. doi: 10.1111/ics. 12057

RiskCom. Health risk science: U.S. National Research Council Risk Assessment Framework, 2018. Available at: $<$ http://www.riskcom.org/framework/health_science/nrc. shtml>.Access in: Oct. 2018.

Sahota, A. Sustainability: how the cosmetics industry is greening up. London: Wiley, 2014.
UL - Underwriters Laboratories. Assessing the safety of personal care products: comparative analysis of health risk assessment frameworks and recommendations for best practices, 2015. Available at: $<$ https://industries.ul.com/ wp-content/uploads/sites/2/2015/06/2015.05.Comparative_Analysis_of_Health_Risk_Assessment_Frameworks_and_Recommendations_for_Best_Practices.pdf $>$. Access in: Oct. 2018.

United States. Environmental Protection Agency (USEPA). Basics of green chemistry, 2019. Available at: $<$ https://www. epa.gov/greenchemistry/basics-green-chemistry\#definition>. Access on: Oct., 2019.

United States. Environmental Protection Agency. Summary of the Pollution Prevent Act, 1990. Available at: <http:// www2.epa.gov/laws-regulations/summary-pollution-prevention-act>. Access in: Oct. 2018.

United States. Food and Drug Administration. Federal Food, Drug and Cosmetic Act, 2002. Available at: $<\mathrm{ht}-$ tps://uscode.house.gov/view.xhtml?req=granuleid:USC-prelim-title21-section321\&num=0\&edition=prelim $>$. Access on: Oct., 2019.

Witorsch, R. J. Critical analysis of endocrine disruptive activity of triclosan and its relevance to human exposure through the use of personal care products. Critical Reviews in Toxicology, 44(6), 535-555, 2014. doi: 10.3109/10408444.2014.910754 